Gut, 1984, 25, 867-873

\title{
Action of secretin on pancreatic enzyme secretion in man. Studies on pure pancreatic juice
}

\author{
L GULlo, PATRIZIA PRIORI, P L COSTA, G MATTIOLI, AND G LABÒ
}

From the Unit for the Study of Pancreatic Disease, Department of Medicine and Gastroenterology, University of Bologna, St. Orsola Hospital, and Division of Surgery, Maggiore Hospital, Bologna, Italy

SUMMARY The action of pure, natural secretin on the pancreatic secretion of enzymes was investigated in six patients with external transduodenal drainage of the main pancreatic duct performed after biliary tract surgery. Secretin infused for five successive 50 minute periods at increasing doses of $0.03,0.1,0.3,0.9$ and 2.7 clinical units $(\mathrm{CU}) / \mathrm{kg} / \mathrm{h}$, produced a dose dependent increase in protein and lipase output. A weak but significant $(\mathrm{p}<0.02)$ increase of enzyme output above the fasting level was already observed with the lowest dose. The maximal output of protein and lipase, observed with the highest dose of secretin infused, corresponded to about $50 \%$ of that induced by maximal doses of cerulein $(100 \mathrm{ng} / \mathrm{kg} / \mathrm{h})$ plus secretin $(1 \mathrm{CU} / \mathrm{kg} / \mathrm{h})$. As far as bicarbonate is concerned, the lowest dose of secretin $(0.03 \mathrm{CU} / \mathrm{kg} / \mathrm{h})$ significantly $(\mathrm{p}<0.001)$ stimulated bicarbonate output. The dose of $0.9 \mathrm{CU} / \mathrm{kg} / \mathrm{h}$ of secretin evoked a bicarbonate output of $526 \pm 49 \mu \mathrm{mol} / \mathrm{min}$; trebling the dose of secretin did not significantly increase the output of bicarbonate above this value. Increasing doses of secretin induced a dose related increase in calcium output. There was a close parallel between calcium and protein outputs, suggesting that the increase in calcium output reflected primarily an increase in the enzyme-associated fraction of pancreatic juice calcium. It is concluded that secretin stimulates pancreatic enzyme secretion in man probably by a direct action on the acinar cells.

The stimulation of water and bicarbonate secretion has been long considered the only action of secretin on pancreatic secretion. In recent years, however, several in vivo and in vitro studies have reported that secretin can also stimulate pancreatic enzyme secretion in some animal species. ${ }^{1-5}$ The influence of secretin on pancreatic enzyme secretion in man is not well defined. Most of the old studies dealing with this problem led to negative conclusions. ${ }^{6-8}$ The rise in enzyme output observed by some investigators after secretin administration, ${ }^{10}$ was generally considered a consequence of a 'washout' of previously secreted enzymes by secretin stimulated flow of fluid through the duct system. ${ }^{6} 10$ The possibility that secretin might stimulate human pancreatic enzyme secretion was raised by Wormsley in $1968 .^{11}$ In a study carried out by means of duodenal intubation, this investigator found that the pancreatic output of trypsin increased with increasing doses of secretin at low levels of

Address for correspondence: Dr Lucio Gullo, Istituto di Clinica Medica e Gastroenterologia, Ospedale S. Orsola, Via Massarenti, 9, 40138 Bologna, Italy.

Received for publication 20 October 1983 stimulation, whereas supramaximal doses of secretin inhibited trypsin secretion. In this study, however, the majority of subjects received Boots secretin, which was contaminated with cholecystokinin,,$^{12}$ and only four subjects received the pure secretin preparation of Jorpes and Mutt. Moreover, these findings were not confirmed in a more recent study by Domschke et al ${ }^{13}$ who evaluated the effects of increasing doses of secretin on pure pancreatic juice collected by endoscopic cannulation of the papilla of Vater and failed to detect any significant effect of the hormone on pancreatic enzyme secretion. The present study was designed in an attempt to obtain more precise information on the action of secretin on pancreatic enzyme secretion in man. In order to avoid possible interferences of bile or other gastrointestinal secretions, the study was carried out directly on pure pancreatic juice.

\section{Methods}

\section{PATIENTS}

Six patients with no clinical history or biochemical signs of pancreatic disease gave informed consent to 
participate in this study. They were five men and one woman, aged $41-68$ years, mean 50 years. Their weights ranged from 50 to $75 \mathrm{~kg}$, with a mean of 63 $\mathrm{kg}$. The method for collecting pure pancreatic juice has been described previously. ${ }^{14} 15$ The patients had transduodenal drainage of the main pancreatic duct performed after papillotomy and sphincteroplasty for common bile duct stones. The appearance of the pancreas at operation was normal in all patients. The drainage was not carried out specifically for the purpose of this study, but as a part of the therapeutic programme to prevent the formation of duodenal fistulae and postoperative acute pancreatitis. ${ }^{16}$ Polyethylene tubes provided with several additional holes in the intraductal portion were inserted into Wirsung's canal to a depth of about $3-4 \mathrm{~cm}$ and were tied to the duodenal wall by a stitch of catgut. Their diameter was accurately selected in each patient according to the calibre of the main pancreatic duct. After insertion of the tube, an intravenous injection of secretin, $0.5 \mathrm{CU} / \mathrm{kg} / \mathrm{h}$, was given to confirm the efficacy of the drainage and to exclude leakage of pancreatic juice around the cannula. Studies were performed in the morning after an overnight fast, and were started at least six days after the operation. It has been shown that pancreatic secretion is depressed during the first two to three days after the operation and returns to normal thereafter. ${ }^{14}{ }^{16}$ In order to avoid the entry of acid into the duodenum, gastric juice was continuously aspirated by a nasogastric tube positioned before the study. Pancreatic juice was collected in ice chilled graduated tubes at 10 minute intervals. Initially, pancreatic juice was collected for five 10 minute periods to estimate the fasting secretion. Then, pure natural secretin (GIH Research Unit, Karolinska Institutet, Stockholm, Sweden) was infused into an arm vein for five successive 50 minute periods at the following increasing rates: $0.03,0 \cdot 1,0 \cdot 3,0.9$, and 2.7 clinical units $(\mathrm{CU}) / \mathrm{kg} / \mathrm{h}$ (equivalent to $2.8,9.3$, 28,84 , and $252 \mathrm{pmol} / \mathrm{kg} / \mathrm{h}$, respectively). Each dose of secretin was dissolved in $100 \mathrm{ml}$ isotonic saline containing $0.3 \%$ human serum albumin. To assess pancreatic enzyme response to maximal stimulation, a second study was carried out on a separate day in five of the six subjects. In this study, an intravenous infusion of cerulein, at a maximal dose ${ }^{17}$ of 100 $\mathrm{ng} / \mathrm{kg} / \mathrm{h}$, plus secretin, $1 \mathrm{CU} / \mathrm{kg} / \mathrm{h}$, was given for 60 minutes.

Each 10 minute sample of pancreatic juice was analysed for volume, bicarbonate, total protein, lipase, and calcium. Bicarbonate was determined by the method of Van Slyke and Neil ${ }^{18}$ total protein by the absorbance at $280 \mathrm{~nm},{ }^{19}$ lipase by the method described by Sarles et al. ${ }^{20}$ and calcium by atomic absorption spectrophotometry. There was no evidence of bile contamination in any of the samples.

The first three 10 minute periods of each 50 minute period of secretin infusion served for equilibration of the pancreatic secretion to increasing doses of secretin. The pancreatic responses were thus calculated from data obtained during the last two 10 minute periods of each dose rate of secretin, when secretory outputs were stable.

The results are presented as mean values \pm SEM. Statistical analysis was performed using Student's $t$ test for paired values.

\section{Results}

Pancreatic secretory data recorded during the five successive 50 minute periods of secretin infusions are summarised in the Table. Generally, there was a steady increase in pancreatic outputs during secretin infusions. A plateau was usually reached within 20-30 minutes from the start of the infusion of each dose of hormone.

Figure 1 shows pancreatic juice volume, bicarbonate concentration, and bicarbonate output during the last two 10 minute periods of each dose rate of secretin. The hormone produced a dose dependent increase in volume and bicarbonate output. A significant rise in pancreatic juice flow and bicarbonate output above the fasting level was already elicited with the lowest dose used $(0.03$ $\mathrm{CU} / \mathrm{kg} / \mathrm{h})$. The maximal volume flow $(4 \cdot 32 \pm 0 \cdot 46$ $\mathrm{ml} / \mathrm{min}$ ) and bicarbonate output $(569 \pm 59 \mu \mathrm{mol} / \mathrm{min})$ was observed during infusion of the highest dose of secretin used $(2.7 \mathrm{CU} / \mathrm{kg} / \mathrm{h})$. The bicarbonate output observed with this dose of secretin, however, was not significantly higher than that attained with 0.9 $\mathrm{CU} / \mathrm{kg} / \mathrm{h}(526 \pm 49 \mu \mathrm{mol} / \mathrm{min})$.

The concentration of bicarbonate rose with increasing dose rates of secretin up to $0.3 \mathrm{CU} / \mathrm{kg} / \mathrm{h}$. At higher hormone doses the concentration declined while the volume continued to increase.

Figure 2 shows the concentrations of protein, lipase, and calcium during the last two 10 minute periods of each dose rate of secretin. These parameters showed a parallel behaviour. In all subjects, the concentrations of protein, lipase, and calcium were greater in the fasting than in postsecretin collections. They were high in the first 10-20 minutes after starting secretin stimulation, likely reflecting a 'washout' phenomenon, and then fell rapidly to a plateau level when secretin stimulation was continued (Table). In each subject, concentration levels declined slightly during infusions of secretin from the dose of 0.03 to the dose of $0.3 \mathrm{CU} / \mathrm{kg} / \mathrm{h}$, and then remained almost constant from the dose of 0.3 to that of $2.7 \mathrm{CU} / \mathrm{kg} / \mathrm{h}$. 

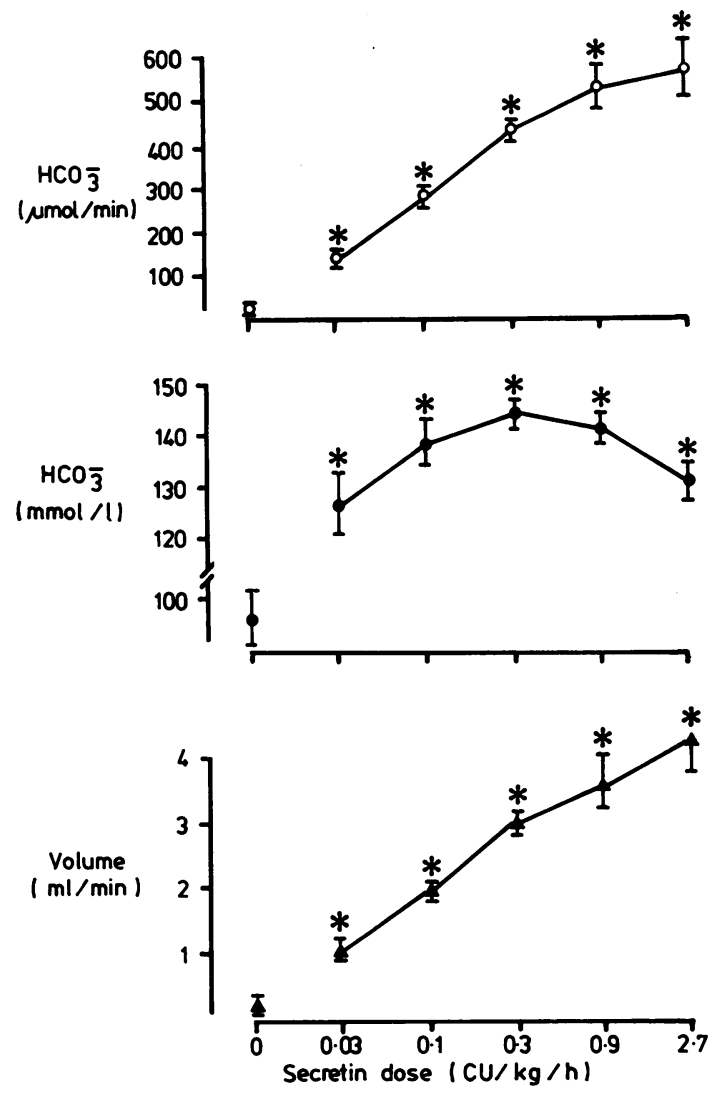

Fig. 1 Pancreatic volume flow, bicarbonate concentration, and bicarbonate output in response to intravenous infusion of graded doses of secretin. Values quoted for volume and bicarbonate output indicate response during last 20 minutes of 50 minute infusion of each dose rate of secretin.

Bicarbonate concentrations indicate mean concentrations during this period. Mean $\pm S E .{ }^{*} p<0.001$ when compared with fasting level.

In analogy to concentrations, outputs of protein, lipase, and calcium (Fig. 3) also behaved in a parallel fashion. The infusion of the lowest dose of secretin $(0.03 \mathrm{CU} / \mathrm{kg} / \mathrm{h})$ produced a weak but significant increase in enzyme $(p<0.02)$ and calcium $(p<0.005)$ output above the fasting level. Increasing doses of secretin induced a dose related increase of these outputs. The mean maximal output of protein, lipase, and calcium, observed during the highest dose of secretin used $(2.7 \mathrm{CU} / \mathrm{kg} / \mathrm{h})$, were $49 \%$, $46 \%$, and $54 \%$ of the protein, lipase, and calcium output, respectively, in response to a maximal dose of cerulein $(100 \mathrm{ng} / \mathrm{kg} / \mathrm{h})$ combined with secretin (1 CU/kg/h).
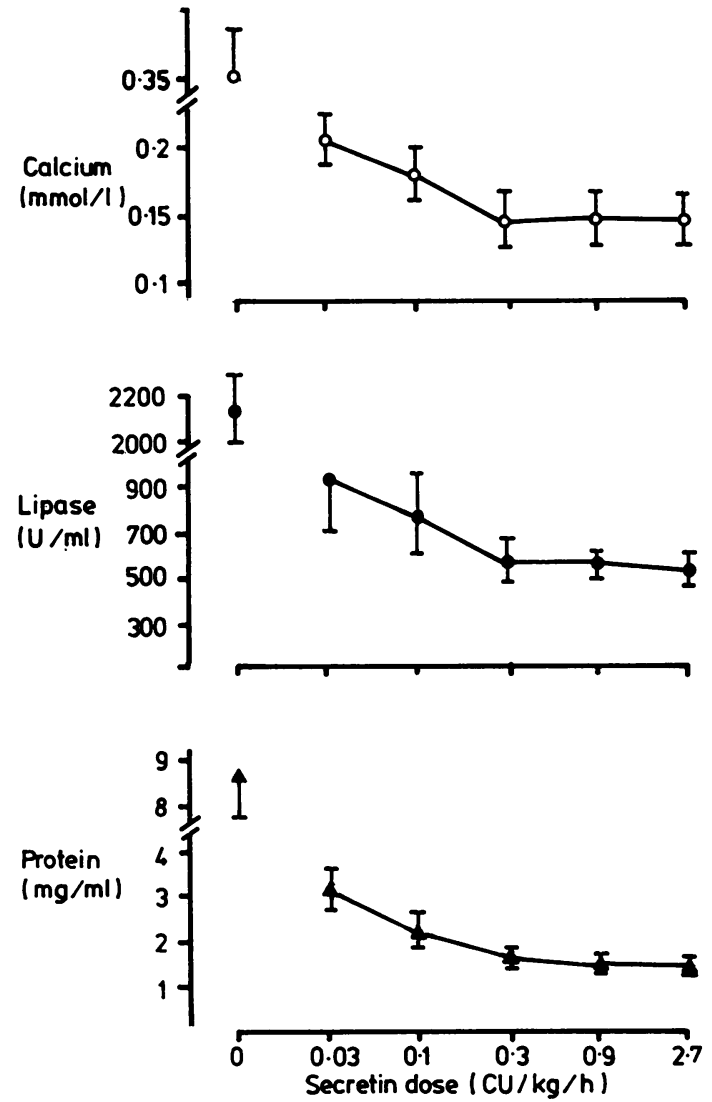

Fig. 2 Protein, lipase, and calcium concentrations during infusion of graded doses of secretin. Values denote mean concentration during last two 10 minute periods of each 50 minute infusion of secretin. Mean $\pm S E$.

\section{Discussion}

The present study shows that secretin is able to stimulate pancreatic enzyme secretion in man. Graded doses of secretin induced graded increase in protein and lipase output, a significant effect being already evident at $0.03 \mathrm{CU} / \mathrm{kg} / \mathrm{h}$. The increase was rather pronounced, the protein and lipase output in response to the highest dose of secretin was about $50 \%$ of that attained with a maximal dose of cerulein, and well sustained as it persisted for the whole period of the study (four hours and 10 minutes). Because of the concomitant increase in the pancreatic juice volume during secretin infusion, 

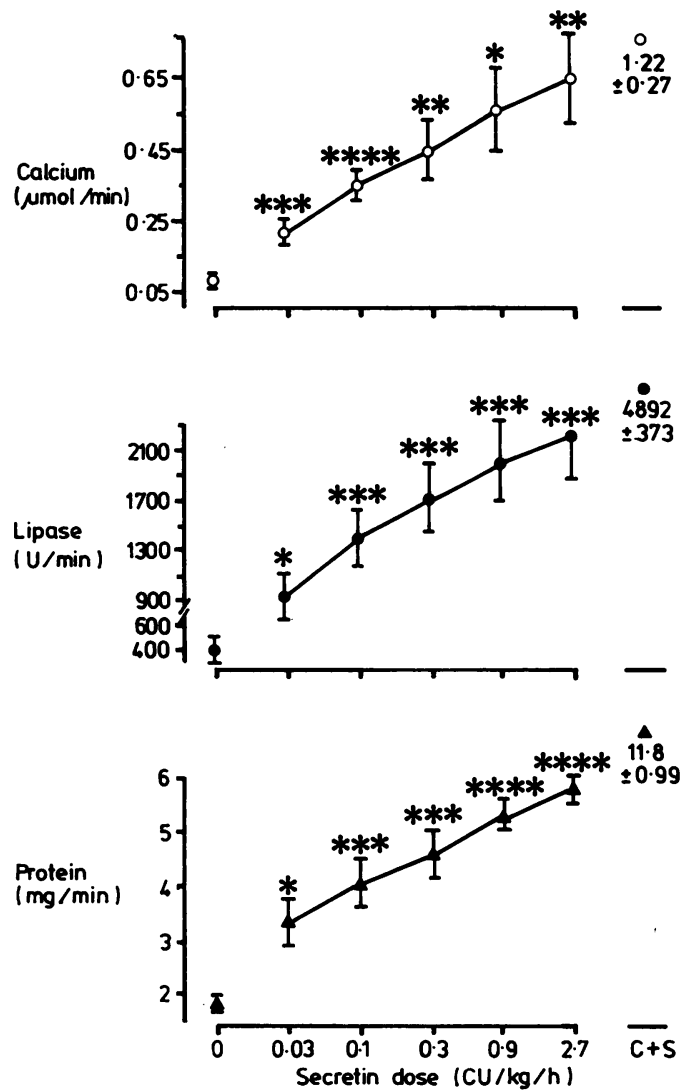

Fig. 3 Protein, lipase, and calcium outputs in response to intravenous infusion of graded doses of secretin. Values indicate response during last 20 minutes of 50 minute infusion of each dose rate of secretin. Mean $\pm S E$. ${ }^{*} p<0.02$, ${ }^{* *} p<0.01,{ }^{* * *} p<0.005,{ }^{* * * *} p<0.001 . C+S=$ pancreatic outputs in response to cerulein, $100 \mathrm{ng} / \mathrm{kg} / \mathrm{h}$, plus secretin, $1 \mathrm{CU} / \mathrm{kg} / \mathrm{h}$.

the concentration of both protein and lipase declined slightly or remained constant. It is unlikely that the increase in protein and lipase output seen in the present study was because of contamination with pancreozymin, as the secretin preparation used did not contain any trace of pancreozymin. ${ }^{21}$ Moreover, several comparative studies of the effects of natural and synthetic secretins on pancreatic secretion failed to show significant differences between the two preparations. ${ }^{122-24}$ It is also highly unlikely that the increase in enzyme output was because of an indirect 'washout' phenomenon. In fact, each dose of secretin was infused at a constant rate for 50 minutes and the enzyme output measured during the last 20 minutes, when a steady state was attained after the early washout. Moreover, the stepwise increase of the infused secretin concentration brought about corresponding increases in enzyme output (during infusion of the last three doses of secretin, from 0.03 to $2.7 \mathrm{CU} / \mathrm{kg} / \mathrm{h}$, protein and lipase concentrations remained practically unchanged while the volume of pancreatic juice continued to rise). We interpret these data as an indication that secretin can act directly on the acinar cells to stimulate enzyme secretion. This possibility is supported also by several experimental findings, including the demonstration of the existence of specific receptors for secretin in the acinar cells, ${ }^{25}$ and the observation that secretin can potentiate cholecystokinin-stimulated enzyme secretion in vitro as well as in vivo. 3122627

The results of this study confirm the observations of Wormsley, ${ }^{11}$ but are at variance with the results of Domschke et al, ${ }^{23}$ who in their study on pure pancreatic juice failed to detect an increase in protein output in response to graded doses of secretin (ranging from 0.03 to $4 \mathrm{CU} / \mathrm{kg} / \mathrm{h}$ ). The latter investigators, however, infused each dose of secretin during a short period ( 20 minutes each dose), which may not have been enough to detect the increase in protein output induced by secretin. We have observed, like others, ${ }^{11} 1728$ that the volume of pancreatic juice and the protein output show a gradual increase and reach the highest levels 20-30 minutes after the beginning of the infusion of each dose of secretin. Moreover, the possibility that premedication needed for endoscopic cannulation of the papilla may have influenced the pancreatic enzyme response to secretin cannot be excluded.

The mechanism through which secretin can increase pancreatic enzyme secretion has received considerable attention. Experimental evidence suggests that in pancreatic acinar cells enzyme secretion can be stimulated by two parallel mechanisms, the first activated by pancreozymin, bombesin, cholinergic agonists and their analogs, the second by secretin and VIP. ${ }^{29}$ This second mechanism involves binding of secretin to the acinar cell receptor, activation of adenylate cyclase, increased cellular cyclic AMP, activation of cyclic AMP-dependent protein kinase, and, after a series of undefined steps, stimulation of enzyme secretion.$^{30}$ It is possible that a similar mechanism is involved in the secretin-induced stimulation of pancreatic enzyme secretion in man, but conclusive evidence for this mechanism in the human acinar cell is lacking.

The effects of secretin on the juice volume and bicarbonate concentration and output are in agreement with previous data in the literature. ${ }^{31-36}$ In particular, they confirm that a secretin dose as low as $0.03 \mathrm{CU} / \mathrm{kg} / \mathrm{h}$ significantly stimulates volume 
and bicarbonate output, ${ }^{3132}$ and that maximal bicarbonate response occurs at a secretin dose of about $1 \mathrm{CU} / \mathrm{kg} / \mathrm{h} .{ }^{33.34}$ Only in the study of Domschke et al $^{13}$ a lower dose (which produced effects much smaller than the maximal observed in the present study) was reported to be maximal. Again, differences in the study protocol (in particular, the short periods of stimulation used by Domschke et al) may possibly account for this discrepancy.

The effect of secretin infusion on calcium secretion into pure human pancreatic juice had never been investigated up to now. With increasing doses of the hormone a close parallelism between calcium and protein was found, similar to that observed after cholecystokinin stimulation. ${ }^{37}$ It is known that calcium is secreted into the pancreatic juice in two fractions, one associated with enzymes, and the other with the electrolyte component. ${ }^{38} 39$ Because of the parallel behaviour of calcium and protein secretion, it is likely that the increase in calcium output during infusions of secretin reflected primarily an increase of the enzyme associated fraction of pancreatic juice calcium.

In conclusion, the results of the present study indicate that, as in several animal species, secretin is able to increase pancreatic enzyme secretion in man. This effect is probably the result of a direct action exerted by the hormone on the acinar cells of the gland.

The authors wish to thank Professors J Meldolesi and $\mathrm{J}$ E Valenzuela for help with this manuscript.

\section{References}

1 Henriksen FW, Möller S. Effect of secretin on the pancreatic secretion of protein. Scand J Gastroenterol 1971; suppl 9: 181-7.

2 Dockray GJ. The action of secretin, cholecystokininpancreozymin and caerulein on pancreatic secretion in the rat. J Physiol 1972; 225: 679-92.

3 Deschodt-Lanckman M, Robberecht P, De Neef P, Labrie F, Christophe J. In vitro interactions of gastrointestinal hormones on cyclic adenosine 3:5-monophosphate levels and amylase output in the rat pancreas. Gastroenterology 1975; 68: 318-25.

4 Gardner JD, Jackson MJ. Regulation of amylase release from dispersed pancreatic acinar cells. $J$ Physiol 1977; 270: 439-54.

5 Sommer H, Kasper H. The action of synthetic secretin, cholecystokinin-octapeptide and combinations of these hormones on the isolated perfused rat pancreas. Hepatogastroenterol [Stuttgart]1981; 28: 311-5.

6 Lagerlöf HO. Pancreatic function and pancreatic disease: studied by means of secretin. Acta Med Scand 1942; suppl 128.

7 Werner B, Mutt V. The pancreatic response in man to the injection of highly purified secretin and of pancreozymin. Scand J Clin Lab Invest 1954; 6: 228-36.

8 Banwell JG, Northam BE, Cooke WT. Secretory response of the human pancreas to continuous intravenous infusion of secretin. Gut 1967; 8: 50-7.

9 Hammarsten E, Agren G, Lagerlöf H. The correlation between secretin dose and pancreatic effect in man. Acta Med Scand 1937; 92: 256-66.

10 Sarles H, Bauer JB, Prezlin G. Etude des injections répétées et des perfusions continues de sécrétine chez l'homme. Arch Fr Mal App Dig 1965; 54: 177-94.

11 Wormsley KG. The action of secretin on the secretion of enzymes by the human pancreas. Scand J Gastroenterol 1968; 3: 183-8.

12 Henriksen FW, Worning $\mathrm{H}$. The interaction of secretin and pancreozymin on the external pancreatic secretion in dogs. Acta Physiol Scand 1967; 70: 241-9.

13 Domschke S, Domschke W, Rösch W, Konturek SJ, Wünsch E, Demling L. Bicarbonate and cyclic AMP content of pure human pancreatic juice in response to graded doses of synthetic secretin. Gastroenterology 1976; 70: 533-6.

14 Gullo L, Costa PL, Fontana G, Tessari R, Serra D, Labò G. Effect of adrenocorticotropic hormone on pure exocrine pancreatic secretion in man. Gastroenterology 1977; 73: 762-4.

15 Gullo L, Priori P, Costa PL et al. Effects of morphine on human pancreatic secretion: studies on pure pancreatic juice. Gut 1982; 23: 739-43.

16 Tournut R, White TT. Water, electrolyte and protein secretions of the human exocrine pancreas in the early post-operative period. Surg Gynecol Obstet 1972; 135: 17-21.

17 Ribet A, Tournut R, Duffaut M, Vaysse N. Use of caerulein with submaximal doses of secretin as a test of pancreatic function in man. Gut 1976; 17: 431-4.

18 Van Slyke DD, Neil JM. The determination of gases in blood and other solutions by vacuum extracting and manometric measurement. J Biol Chem 1924; 61: 523-73.

19 Figarella C, Ribeiro T. The assay of human pancreatic phospholipase $\mathrm{A}$ in pancreatic juice and duodenal contents. Scand J Gastroenterol 1971; 6: 133-7.

20 Sarles H, Taulier J, Figarella C. Dosage de la lipase dans le suc duodenal. Rev Fr Etud Clin Biol 1963; 8: 706-7.

21 Mutt V. Secretin: Isolation, structure, and functions. In: Glass GBJ, ed. Gastrointestinal hormones. New York: Raven Press, 1980; 85-126.

22 Farooq O, Sturdevant RAL, Isenberg JI. Comparison of synthetic and natural porcine secretins on human pancreatic secretion. Gastroenterology 1974; 66: 204-9.

23 Lankisch PG, Creutzfeldt W. Effect of synthetic and natural secretin on the function of the exocrine pancreas in man. Digestion 1981; 22: 61-5.

24 Beglinger C, Gyr K, Werth B, Keller U, Girard J. Comparative effects of synthetic and natural secretin on pancreatic secretion and on secretin, insulin and glucagon levels in man. Dig Dis Sci 1982; 27: 231-3. 
25 Christophe JP, Conlon TP, Gardner JD. Interaction of porcine vasoactive intestinal peptide with dispersed pancreatic acinar cells from the guinea pig. Binding of radioiodinated peptide. J Biol Chem 1976; 251: 462934.

26 Wormsley KG. A comparison of the response to secretin, pancreozymin and a combination of these hormones in man. Scand J Gastroenterol 1969; 4: 413-7.

27 Fölsch UR, Wormsley KG. Pancreatic enzyme response to secretin and cholecystokinin-pancreozymin in the rat. $J$ Physiol 1973; 234: 79-94.

28 Escourrou J, Frexinos J, Ribet A. Biochemical studies of pancreatic juice collected by duodenal aspiration and endoscopic cannulation of the main pancreatic duct. Dig Dis Sci 1978; 23: 173-7.

29 Gardner JD. Regulation of pancreatic exocrine function in vitro: initial steps in the actions of secretagogues. Ann Rev Physiol 1979; 41: 55-66.

30 Jensen RT, Gardner JD. Receptors mediating the actions of gastrointestinal peptides and other secretagogues on pancreatic acinar cells. In: Beers RF, Bassett EG, eds. Polypeptide hormones. New York: Raven Press, 1980; 395-412.

31 Schaffalitzky de Muckadell OB, Fahrenkrug J, WattBoolsen S, Worning $H$. Pancreatic response and plasma secretin concentration during infusion of low dose secretin in man. Scand J Gastroenterol 1978; 13: 305-11.
32 Greenberg GR, Domschke S, Domschke W, Rösch W, Bloom SR. Effect of low dose secretin and caerulein on pure pancreatic bicarbonate secretion and plasma secretin in man. Acta Hepatogastroenterol [Stuttgart] 1979; 26: 478-81.

33 Konturek SJ. Pancreatic dose-response curves to intravenous secretin in man. Gastroenterology 1970; 58: 828-32.

34 Häcki WH, Bloom SR, Mitznegg $\mathrm{P}$ et al. Plasma secretin and pancreatic bicarbonate response to exogenous secretin in man. Gut 1977; 18: 191-5.

35 Wormsley KG. Response to secretin in man. Gastroenterology 1968; 54: 197-209.

36 Ribet A, Pascal JP, Sannou N. Etude de la fonction exocrine du pancreas humain par les perfusions continues de secretine. I. Influence des doses croissantes sur la secretion hydroelectrolytique. Arch Fr Mal App Dig 1967; 56: 677-84.

37 Goebell H, Baltzer G, Schlott KA, Bode C. Parallel secretion of calcium and enzymes by the human pancreas. Digestion 1973; 8: 336-46.

38 Argent BE, Case RM, Scratcherd T. Amylase secretion by the perfused cat pancreas in relation to the secretion of calcium and other electrolytes and as influenced by the external ionic environment. J Physiol 1973; 230: 575-93.

39 Ceccarelli B, Clemente F, Meldolesi J. Secretion of calcium in pancreatic juice. $J$ Physiol 1975; 245: 617-38 